\title{
Evolutionary Aesthetics and the Hebrew Male Body: Study of the Zionist metamorphosis of the Jewish masculine body and the birth of the "muscle Jew"
}

\author{
Yosra Amraoui
}

\begin{abstract}
The ancient history of the Jewish people testifies of many a reference to forced exiles imposed on the Jews resulting in a centuries-long journey of wandering and persecution that culminated in the Nazi Holocaust of the $20^{\text {th }}$ century. It is argued by theorists of the body that this history of non-resistance on the part of the Jews affected the physiognomy of the Jewish male in such a tremendous manner that physically transformed the stature of the Jew into one that is frail, short-sized and pale. It was not until the late $19^{\text {th }}$ century that the Jewish thinker Max Nordau (co-founder of the World Zionist Organization and close friend to Theodor Herzl) introduced the image of the "muscle Jew" at the Second Zionist Congress held in 1898 as an idealistic aspiration necessary to the realization of the Zionist scheme. "Muscular Judaism" then evolved into a body of studies and theories that examined the role of history and collective memory in the physical "regeneration" of the male Jewish body into one that is militarily fit to fight for self reaffirmation. This paper purposefully introduces the background of this body of theories and literature and frames it within the field of evolutionary aesthetics for a better demonstration of the journey accompanying the metamorphosis of the male Jewish body for Zionist and political ends. The present study also examines the related implications of this physical change on the birth of the concept of the "New Hebrew Man" and on the violent behavior of Israeli military recruits in the years preceding and following the creation of Israel in 1948.
\end{abstract}

Key words: evolutionary aesthetics - metamorphosis - muscular Judaism - the new Hebrew man

The vast field of evolutionary aesthetics stipulates that "all adaptations are aesthetic adaptations, because all adaptations interact in some way with the environment, external or internal, and prefer certain states to others." (Thornhill 9) ${ }^{1}$ The human body, among other aesthetic manifestations of life, evolves thus in sync with the evolution/devolution of the milieu and the conditions surrounding it which is why it is essential to cast a look upon the history of the body under study before commenting on its metamorphosis. As a complement to evolutionary aesthetics, there exists a recent field of revolutionary aesthetics that presents itself as a form of "protest and social metamorphosis for the re-humanisation in a given social matrix." (Nwagbara 9) This paper examines the metamorphosis of the Jewish body within the broad fields of evolutionary and revolutionary aesthetics in an attempt at highlighting the impact of the traumatic history of the Jews on the devolution and then in the evolution of the Jewish male body throughout history.

As the Jews suffered both at the moral and physical levels due to a long history of oppression and persecution, it is interestingly argued that this centuries-long suffering affected the physiognomy of the Jewish male at the long run and was one of the causes why Eastern Jews in particular were viewed as a passive and an easy prey to severe discrimination in their host countries. A close look at the history of Jewish persecution from the $11^{\text {th }}$ to the $20^{\text {th }}$ century provides for ground to assert that the Jewish life style transformed greatly from decent and/or average into a ghetto-life style. The incessant wandering and the history of expulsions only worsened the poor conditions in which the Jews lived with their families and sealed their acceptance of the oppression directed at them until the rise of the Zionist movement.

Moreover, and as argued by Patricia Vertinsky in her article "Anti-Semitism, Physical Culture and the Jews' Foot," anti-Semitic thinking led a considerable number of scientists and thinkers-mainly of German origins $^{2}$ - to start a wave of stereotypes against the Jews regarding the latter's short size or short arm length or even related to the so-called Jews' effeminate way of speaking. Some studies reported that the average height of Jewish males was $1,610 \mathrm{~mm}$; therefore they were considered a lot shorter than non Jewish Ukrainian or Polish males, which was also a drive for governments to consider them unfit for military service. As to the effeminate allure of the Jewish male body, scientists linked it to a noticeable short arm length. As anthropologists usually calculate the length of stretched arms in comparison with the body height they noticed that in the case of male Jews, "the distance between the tip of the middle fingers of their [the Jews'] left and right hands was $4,3 \mathrm{~cm}$

\footnotetext{
${ }^{1}$ Randy Thornhill. "Darwinian Aesthetics Informs Traditional Aesthetics" published in the volume Evolutionary Aesthetics edited by Eckart Voland and Karl Grammer, p9 (2003)

${ }^{2}$ Such as M. Englander, H. Hoppe, A. Kiefer, H. Singer and A. Elkind
} 
below their height" "which is usually seen as a female characteristic. In his article entitled "Physical Characteristics of the Jews," Klaus Hoedl further speculates on the Jewish male effeminacy and points out that the ascription of female traits to the Jewish body was not simply based on a comparison of its characteristics to that of a woman's. Effeminacy was also attributed to the male Jew because his body allegedly functioned differently, its whole social performance was believed to differ from the male non-Jewish body. In the nonJewish, bourgeois society, manliness was thought to articulate itself in the military. Women were believed to be physically incapable to become soldiers, therefore they could not be manly. And the same was held to be true with respect to Jews. Again, it was their body that accounted for their deficient fitness for the army. ${ }^{4}$

Such kinds of stereotypes typified the physiognomy of the Jewish man as frail and un-inclined to engage in manly activities, wars or even defense tactics to preserve his community, which ultimately classified the Jews as a weak and passive people. What further reinforced this type of judgmental thinking were the successive attacks on Eastern Jews in different parts of the world and the latter's absence of reaction, acceptance of martyrdom being one of the most worshipped ideals spread by the Jewish pious movement called the Hasidei movement that spread in the $18^{\text {th }}$ century. This movement's literary productions were aimed at leading the Jews of Germany towards a stricter contemplation and application of the commandments of Judaism. For the Hasidim (the followers of this movement), the ultimate manifestation of faith and loyalty to God is through martyrdom, a word that is framed in Yiddish as kiddush hashem, literally meaning "the sanctification of the Holy Name," an act of glory for which every Hasid longs. ${ }^{5}$

\section{Aspects of the traumatic history of Eastern European Jews}

The dilemma of Eastern European Jewry or as they are also called the Ashkenazi Jews was unique in the way these communities suffered from the utmost forms of humiliation and atrocities due to several libels attached to them. The first predicament took place from 1298 to 1299 in the course of which the Jews were accused of having desecrated Germany, an accusation for which 140 Ashkenazi communities perished. The second crisis hit 110 Jewish communities which were destroyed by rioting peasants between the years 1336 and 1337. The third and most devastating blow took place from 1348 to 1350 , especially in the two years accompanying the contagious plague that ravaged Europe nicknamed the Black Death (1348-1349). ${ }^{6}$

However, the main reason behind the death of over 300 Ashkenazi Jewish communities at the time the Black Death was spread was not the fatal disease per se. All European Jews were accused of having conspired to poison the water sources, ${ }^{7}$ a libel that tarnished the Jews' reputation and forced European authorities to torture them in order to extract confessions. Under torture, some Jews confessed and the news rapidly spread all over Europe resulting in mass massacres of the Jews that were either committed by the populations or by the authorities; some preferred to just expel the Jews from their lands. ${ }^{8}$ As for the Jews of the city of Mainz, Germany for instance, they committed suicide by setting fire on their houses and streets and sometimes by digging mass graves and leaping into them willingly dancing and praying, a typically hasidic Ashkenazi belief in the holistic nature of martyrdom "that enabled European Jewry to emerge spiritually unscathed from the avalanche of hatred and cruelty released on the Jews by the Christians of Europe."9

The large size of the German empire allowed the expelled Ashkenazi communities to easily find refuge within the empire's non German neighborhoods in which German Jews did not feel so much alienated. Yet, Ashkenazi communities were soon allowed to return to certain German areas (Erfurt, Nuremberg, Ulm, Speyer, Worms and Trier) for no one else could fulfill their positions as moneylenders. But in spite of that, large numbers of Ashkenazi Jews favored the migration to Poland starting from the mid $14^{\text {th }}$ century and had gradually taken refuge there until the mid $17^{\text {th }}$ century. ${ }^{10}$

Blood libels increased with the upcoming of the $15^{\text {th }}$ and $16^{\text {th }}$ centuries, Ashkenazi refugees were expelled from Prague (1400) and were successively expelled from the city of Mainz on several occasions in the years $1420,1438,1462$, and 1473. These communities were forced to leave Austria in 1420-21 and Cologne in 1424; they were also forced out of Augsburg in 1440. Accusations for host desecration resurfaced again in 1492, after which Ashkenazi Jews were expelled from the cities of Mecklenburg and Magdeburg in 1493. In the second half of the $15^{\text {th }}$ century they were driven out of Bavaria, Franconia and Swabia and out of Nuremberg in 1499. In 1510, all the Ashkenazi communities of Brandenburg and Alsace were forced out followed by the

\footnotetext{
${ }^{3}$ Heinrich Singer in 1904

${ }^{4}$ Klaus Hoedl "Physical Characteristics of the Jews" published in the journal of Jewish Studies at the CEU (1999-2001). Article available online at http://web.ceu.hu/jewishstudies/pdf/01_hoedl.pdf accessed on 08/10/2012

${ }^{5}$ Encyclopaedia Judaica, V. 08, p. 388

6 "The Black Death: epidemic of various contagious diseases, bubonic, septicemic, and pneumonic, all caused by the same bacillus, pasteurella pestis, a combination of which raged throughout Europe between 1348 and 1350.” Encyclopaedia Judaica, V. 03 , p. 731

${ }_{7}^{7}$ Encyclopaedia Judaica, V. 03, p. 731

${ }^{8}$ Encyclopaedia Judaica, V. 09, p. 220

${ }^{9}$ Encyclopaedia Judaica, V. 03, p. 733

${ }^{10}$ Encyclopaedia Judaica, V. 07, p. 522
} 
communities of Regensburg. ${ }^{11}$ Following these expulsions, German Jews moved to areas such as Bohemia, Moravia, Lithuania and Poland. However, following the Chmielnicki massacres that took place in Poland in 1648 , a large part of Ashkenazim returned to Western Europe seeking asylum from the persecutors. ${ }^{12}$

Hundreds of Ashkenazi communities and tens of thousands of Jews were reported to have perished during the Chmielnicki massacres, also nicknamed the holocaust of Polish Jewry. The larger part of the events took place from May to November 1648 orchestrated by Bogdan Chmielnicki, the "leader of the Cossack [the East Slavic communities] and peasant uprising against Polish rule in the Ukraine." ${ }^{13}$ Chmielnicki's campaigns revolved around causing social and religious unrest in the country in an attempt to throw out Polish rule out of the Ukraine hoping to make of it an independent state. The main reason behind hostility towards and attacks on the Jews of Poland during that crisis was that local communities wanted to convert them to Christianity by force, failure to follow the orders resulted in mass murders of those who refused and of their families as well. ${ }^{14}$ The Ashkenazim who remained in Poland during the $19^{\text {th }}$ century witnessed the Russian annexation of Polish lands and were thus subjugated to the Russian Czarist rule. The Jews of Russia, who formed a large portion of the society, suffered from the historically notorious Russian pogroms which were crimes committed by Russian peasants aimed at massacring the Jewish communities and blaming them for taking all the jobs and blaming the Jews for the peasants' famine and misfortune. Finally, the suffering of German Jews crowned the trauma series with the Nazi Holocaust.

The brief history provided above partly shows the extent to which Jewish suffering incited no reaction on the part of Jewish men apart from leaving or surrendering to the attacks directed at their communities. It appears as if these communities were to accept this fate out of religious conviction. As previously shown, it was also widely believed by the Jews that martyrdom is a spiritual act of strength, an act that did not require any physical muscles or body building. These beliefs were largely adopted by the Hebrew society affecting the physiognomy of the Jewish men until the rise of the Zionist movement and more specifically with the birth of the "new muscle Jew" concept that was started by the Zionist activist, literary critic and co-founder of the World Zionist Organisation Max Nordau.

\section{Max Nordau and the call for a Jewish physical metamorphosis}

In his famous speech delivered at the First Zionist Congress held in Basle in 1897, Nordau depicted the general backdrop in which his co-religionists lived in those times surrounding the end of the $19^{\text {th }}$ century as miserable. He first shed light on the different aspects of Jewish wretchedness and summarized it as being "the daily distress of the body, anxiety for every following day, the painful fight for the maintenance of a bare existence." "He also mentioned how his brethrens had now become accustomed to "the enmity of the mob" and to "bodily wounds" and to "bleeding to death". The Jew has become so accustomed to social intolerance that he secluded himself and his family in the "ghettos". Max Nordau did not blame the discrimination of the authorities of the host countries in which the Jews lived, he literally affirmed that life in the ghetto was self-inflicted and framed it in his speech as follows: "the authorities did not shut him [the Jew] up in a ghetto, he built one for himself. He would dwell with his own." This type of misery according to Nordau weakened and "destroyed" the Jewish body.

After presenting the several aspects that physically affected his co-religionists in his first speech, Nordau moved to the next step in his second speech presented at the Second Zionist Congress held in Basel the following year. It was in that speech that he created the ideal of the "muscle Jew" (Presner 1). This new appealing concept called for the necessity to "corporeally [ensure] the physical rearing of one's offspring in order to create a lost muscular Judaism once again." "Nordau's use of the Jewish collective memory is in the heart of Zionist tactics as he recalls the memories of the ancient might of the people of Israel before they were expelled from their land by the Babylonians in the $6^{\text {th }}$ century B.C. One can also find in this call a reference to the powerful image of the once chosen people before the diasporic curse took place and the wandering started.

According to Todd Samuel Presner, writer of Muscular Judaism: the Jewish body and the politics of regeneration (2007), a comprehensive study on which I principally relied in writing this paper, Zionists of the $19^{\text {th }}$ century believed that achieving national ambitions and creating a state for the Jews can only be realized through spiritual and physical rebirth. Presner says in this regard

Although fundamentally connected to the Jewish body, "muscular Judaism" was not about weighttraining or bodybuilding per se; rather it was about the cultivation of certain corporeal and moral ideals such as

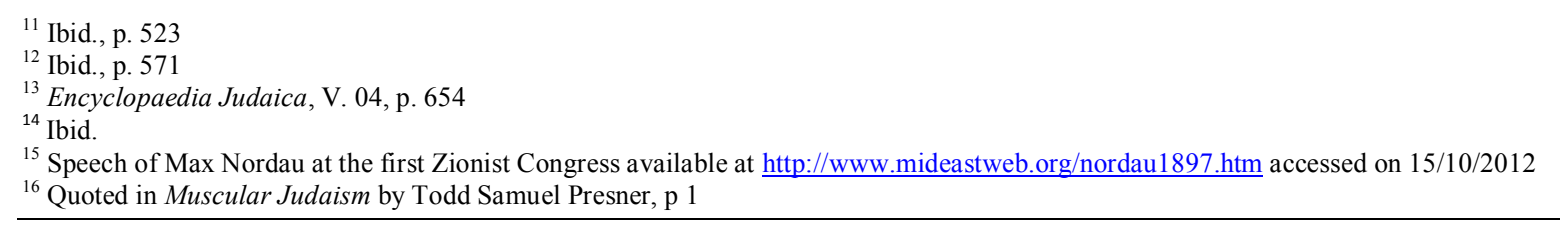


discipline, agility, and strength, which would help form a regenerated race of healthy, physically fit, nationally minded, and militarily strong Jews (2).

The ideas of rebirth and/or regeneration are extremely powerful and appealing in such a way that "Muscular Judaism" gained fame after the Second Zionist Congress. It is reported that Max Nordau himself was not aware of the repercussions of his calls for the Jewish physical metamorphosis until two years after his 1898 speech (Presner 1). "Muscular Judaism" then evolved into a body of studies and theories that examined the role of history and collective memory in the physical "regeneration" of the male Jewish body into one that is militarily fit to fight for self reaffirmation. Moreover, sports associations under the mythic names Bar Kochba ${ }^{17}$ and the Maccabees ${ }^{18}$ specialized in gymnastics joined the Zionist movement and played a significant role in shaping a new physical image of the male Jew as of the late 1890s (Presner 2). The name Bar Kochba in particular resonated as an ancient call from the past to see the ancient Jewish warriors reborn in their fittest shape as it refers to the name of the mythic rebel and leader of the Jewish rebellion against Roman colonization in the year 132 C.E.: Bar Kokhba. This hero was associated with messianic hopes in ancient Jewish history and was even thought to rely mostly on his physical powers rather than on divine help. ${ }^{19}$

In an article he published in the German journal Die Juedische Turnzeitung (the Jewish Gymnastics Journal) in June 1903 under the title "Jewry of Muscle,",20 and that was republished in Zionistische Schriften (1909), Nordau wrote a powerful piece to memorize the mighty heroes of the past and to praise the role played by the gymnastics' club in the following manner worth to be quoted fully

But now, all coercion has become a memory of the past, and at least we are allowed space enough for our bodies to live again. Let us take up our oldest traditions; let us once more become deep chested, sturdy, sharp-eyed men. This desire of going back to a glorious past finds a strong expression in the name which the Jewish gymnastic club in Berlin has chosen for itself. Bar Kokhba was a hero who refused to know defeat. When in the end victory eluded him, he knew how to die. Bar Kokhba was the last embodiment in world history of a bellicose, militant Jewry. To evoke the name of Bar Kokhba is an unmistakable sign of ambition. But ambition is well suited for gymnasts striving for perfection. For no other people will gymnastics fulfill a more educational purpose than for us Jews. It shall straighten us in body and in character. It shall give us selfconfidence, although our enemies maintain that we already have too much self-confidence as it is. But who knows better than we do that their imputations are wrong. We completely lack a sober confidence in our physical prowess. Our new muscle-Jews have not yet regained the heroism of our forefathers who in large numbers eagerly entered the sport arenas in order to take part in competition and to pit themselves against the highly trained Hellenistic athletes and the powerful Nordic barbarians. But morally, even now the new muscleJews surpass their ancestors, for the ancient Jewish circus fighters were ashamed of their Judaism and tried to conceal the sign of the Covenant by means of a surgical operation, while the members of the "Bar Kochba [Association]" loudly and proudly affirm their national loyalty. May the Jewish gymnastic club flourish and thrive and become an example to be imitated in all the centers of Jewish life! ${ }^{21}$

One cannot fail to notice in the above speech the confident tone with which Nordau predicts a muscular Jewish uprising through the practice of gymnastics and more importantly through the remembrance of the heroic Jewish past: more attachment to Judaism. Unlike the ancient Jewish gymnasts who were forced to hide their religion, the new muscle Jew of the $19^{\text {th }}$ century faces his fears with an unprecedented fervor and a unique physicality that is yet to be built and reinforced as predicted by Nordau.

The present examination of the embodiment/physicality of a burgeoning protest movement illustrates the link between the historical knowledge put at the disposal of the targeted/addressed society and the staging of the different steps of metamorphosis of the body to be called into action. This study-which fits deeply in the heart of both evolutionary and revolutionary aesthetics - not only drives us to assess the significance and the need for a male body metamorphosis in the Jewish case but also to examine the implications of the whole body building process on Jewish militia at the time Zionism was put into test by the mid twentieth century. The following concluding part presents a few of the consequences of the Jewish regeneration movement that was started by Nordau in 1898 .

\section{.The role of "Muscular Judaism" in the rise of the Haganah (the future Israeli Defense Forces) and consequently in the rebirth of the New Hebrew Man}

What was started by Nordau was ultimately reinforced by the Bar Kochba gymnastics association as it published a voluminous work intended to commemorate the "Physical Renaissance of the Jews" (the German

\footnotetext{
${ }_{17}^{17}$ This club opened in Berlin in 1898 and inspired several clubs to open throughout Europe

${ }^{18}$ The Maccabees were a rebellious army that took hold of the kingdom of Judea in 164 B.C. during the reign of which the land of Israel expanded through conquest and the Jewish religion was asserted more than ever.

${ }^{19}$ Encyclopaedia Judaica, Volume 3, second edition, p 157

${ }^{20}$ Translated by J. Hessing, pp 379-81

${ }^{21}$ Quoted from The Jew in the Modern World: A Documentary History, 2nd edition, ed. Paul Mendes-Flohr and Jehuda Reinharz (New York and Oxford, 1995).
} 
title was Körperliche Renaissance der Juden) (Presner 106). Presner mentions that this work contains essays written by doctors and sports experts who outlined "the benefits of gymnastics, fitness, sports, farming, and military service for the regeneration of the Jewish people" (Presner 106). This work inspired a German gymnastics club called Turnverein to write in its membership charter that its primary aim is to ensure financial sponsoring to Jewish gymnastics "for the improvement of the Jewish body" (Ibid.). In this regard, Steven Reiss asserts that "central European Jewish sports clubs were ethnic, rather than devotional, and stressed Muscular Judaism and Zionism."22

These improvement operations did not only target individual Jewish bodies but were aimed at inspiring the whole Jewish population to become healthy, physically fit for the greater aims of Zionism. Presner thinks that Nordau's project enthused a whole range of studies that can fit within what he termed the "bio-politics of the population" which is the study of "births and mortality, propagation, life expectancy, health and disease, progeny, racial characteristics, hygiene practices, fertility and eventually eugenics" (Presner 111). Along with cultivating the body, Presner thinks, goes the cultivation of the nation (112). The Bar Kochba association of gymnastics gave thus birth to far more enlarged bodies operating in the same field but at a greater scale such as "the Jewish Gymnastics Federation" started in 1903, the Constitution of which stipulated that the purpose of the Jewish Gymnastics Federation is to cultivate gymnastics as the means of corporeal improvement of the Jewish people in the sense of the national-Jewish idea. By the term national-Judaism, we mean the consciousness of belonging together of all Jews due to their shared descent and history as well as the will to preserve the Jewish racial community on this basis (Quoted by Presner in Muscular Judaism 121).

The members of this sports association engaged in entertaining the attendees of the Zionist Congresses and their performances expanded at a larger European scale, they were even reported to have travelled to Palestine in several occasions as well (Presner 122). The rise and spread of such powerful "Jewish body culture" went hand in hand with the Zionist agenda in such a way that the outstanding Jewish gymnastics journal Die Jüdische Turnzeitung would distinguish itself [in the years to follow] by disseminating an extraordinary range of articles and ideas on Jewish 'body culture', many of which (but not all) were in accord with the emergence and development of Zionist politics. Over more than three decades, the journal published historical articles on ancient Jewish greatness, heroic personages, exercise and training routines for the improvement of musculature, photographs of the gymnastic associations and muscle Jews, inspirational fitness stories, military battle songs, schedules and results of various gymnastics competitions, hygiene programs, and medical discussions of the benefits of sun, light, and movement for a healthy body and a potent sexuality (Presner 124).

These essays were destined to wipe out the stereotypical image of the coward, submissive and physically weak Jew that resulted in self-hatred among Jews themselves, a spiritual brainwashing operation that had physical and more palpable goals. The fact that the Jews were not allowed into the military in several European countries such as Germany for instance, meant that Jews could not be counted upon to protect their nation and were therefore regarded as useless and unmanly. And because Presner does not wish to make of his book on "Muscular Judaism" an "interrogation of Israel or contemporary muscle Jews [being merely an] attempt to understand how, when and why Jews became muscular in the first place" as he indicates in his concluding remarks (Presner 217), I will dedicate my last part of this paper to interrogate the tactics of the Israeli defense forces and to question the ferocity with which they came to be known in their occupation of the land of Palestine.

The field of revolutionary aesthetics is thought to be a form of the "sheer collective awakened consciousness of the oppressed to change an unjust order" (Amuta 1986). It is also portrayed as "the combat that brings about freeing of humanity from the cordon of oppression" (Udenta 1993). ${ }^{23}$ Therefore, the social vision that should have accompanied the rebirth of the Jewish nation should never have been associated with fierce displacement strategies that would target another people and forcibly settle in their land. What the Haganah forces did in the years 1947 and 1948 under the commanding orders of David Ben-Gurion was an intended and planned colonization of the land of Palestine that necessitated the forced expulsion of its inhabitants in a war the Zionists called the "War of Independence". This war was waged under the watchful eyes of the British and American administrations that had ended the Mandate on Palestine in the late 1940s, and was performed by the trained forces of the Haganah, mostly volunteers not recruits by then; Haganah literally meaning "defense" in Hebrew. $^{24}$

The Haganah forces were created upon the start of the British Mandate over Palestine in the 1920s. At first, there was a common belief that there was no need for a Jewish military force in the area as it was supposedly protected by the British; but as soon as Palestinian Arabs noticed the surge of the aliyahs (traumatic Jewish waves of immigration to Palestine) they suspected the establishment of a Jewish national settlement in their land and thus started rioting against the British and the Jews alike. The latter were stuck between their

\footnotetext{
${ }^{22}$ Steven Reiss in his article "Anti-Semitism and Sport in Central Europe and the United States 1870-1932", p 115

${ }^{23}$ As put by Nwagbara in the journal of Jewish Studies at the CEU (1999-2001)

${ }^{24} \mathrm{http}: / /$ www.britannica.com/EBchecked/topic/251461/Haganah accessed on 15/10/2012
} 
original promises to grant self government to Arab countries under their trusteeship and between their proZionist inclinations demonstrated through the Sykes-Picot agreement (1916) and the Balfour Declaration (1917). The Jewish military volunteers and recruits were then trained to fight Arab uprisings in the region ${ }^{25}$ and protect the Jewish settlements (the Yishuv) in Palestine in spite of the fact that the whole Jewish defense unit concept was outlawed by the British mandatory administration in Palestine. ${ }^{26}$ The British even accused some of the Haganah members of having stolen arms from British depots. ${ }^{27}$ The Haganah members/future soldiers started as volunteers, and then Jewish sponsoring promoted them to become the "official" defenders of the Yishuv.

However, the Israeli archives today unravel a history of oppression committed by the Haganah soldiers against the indigenous population of Palestine in which entire villages were destroyed and whole communities were wiped out in the most ferocious manner that existed. The Israeli revisionist movement of the 1980s exposed documents that proved the Jewish military brutality on the eve of the American recognition of a Jewish state in Palestine. A fierce opponent of the so called fabricated "official" version of the history of Israel is Ilan Pappé (the Israeli historian and Professor of Political Sciences at Haifa University) who detailed the military interventions of the Haganah forces in Palestine in 1948 in his article "The 1948 Ethnic Cleansing of Palestine" (2006) as follows Military orders were dispatched to units on the ground to prepare for the systematic expulsion of Palestinians from vast areas of the country. The orders came with a detailed description of the methods to be used to forcibly evict the people: large-scale intimidation; laying siege to and bombarding villages and population centers; setting fire to homes, properties, and goods; expelling residents; demolishing homes; and, finally, planting mines in the rubble to prevent the expelled inhabitants from returning. Each unit was issued its own list of villages and neighborhoods to target in keeping with the master plan. Code-named Plan D (Dalet in Hebrew), this was the fourth and final version of vaguer plans outlining the fate that was in store for the native population of Palestine. ${ }^{28}$

Several other Israeli revisionist historians such as Benny Morris and Avi Shlaim examined other aspects of the available archival materials to undermine certain myths about the foundation of the State of Israel and joined Pappé in his condemnation and/or exposure of the military operations that expelled the Palestinians out of their rightful land. The concluding remark though is that the Jewish metamorphosis from a stereotypically weak and submissive Jew to a muscle Jew is one that led to a whole range of unfortunate events surrounding the forced abduction of Palestinian territories and the ensuing crimes that touched the original inhabitants of the land. These desolate events which resulted in the falsification of historical facts that testified of Israeli military crimes against the Palestinians surprisingly led to an academic post-Zionist current that claimed it was high time for the Israelis to learn from past lessons and reinvent the New Hebrew Man, one that aspires to be better than those who abducted the land from its owners.

The British Palestinian historian and critic Nur Masalha describes the post-Zionists' mild criticism of Israel's history as an act of "patriotic self censorship. ${ }^{29}$ He denounces the fact that most of them remained Zionists even after the revelations they published. Yet Masalha also thinks that Israeli academia's return to history is part of a project that aims at the recreation of the "New Hebrew Man" ${ }^{30}$ through the [re]writing of a new history. "The 'new/young' versus 'old' theme is at the heart of the 'Zionist revolution' [he says]. Zionist new thinking is deeply embedded in Israeli rhetoric and is central to the construction of an Israeli identity based on the so-called return to history and the construction of a New Judea and New Jerusalem. ${ }^{31}$ " With this affirmation, Masalha hits a sensitive point in the analysis of the reasons behind and consequences of the rise of Post-Zionism in Israel. In order to corroborate his findings, Masalha resorts to Shlomo Sand's ${ }^{32}$ conclusions advanced in his revelatory book The Invention of the Jewish People (2009).

In the introduction to the above-mentioned book, Sand quotes Karl Deutsch when he says that "a nation is a group of persons united by a common error about their ancestry and a common dislike of their neighbors" (Sand 1). Then he gradually demonstrates how the Jews have always resorted to their past in order to extract fragments of their journey from the myths that accompanied it throughout the centuries, which eventually formed what is now known as Jewish/Israeli history. This history that was built and nurtured by legends is undermined by post-Zionist discourse, as Sand puts it, producing "unfamiliar pictures of the past" (Sand $\mathrm{x}$ Preface to the English edition).

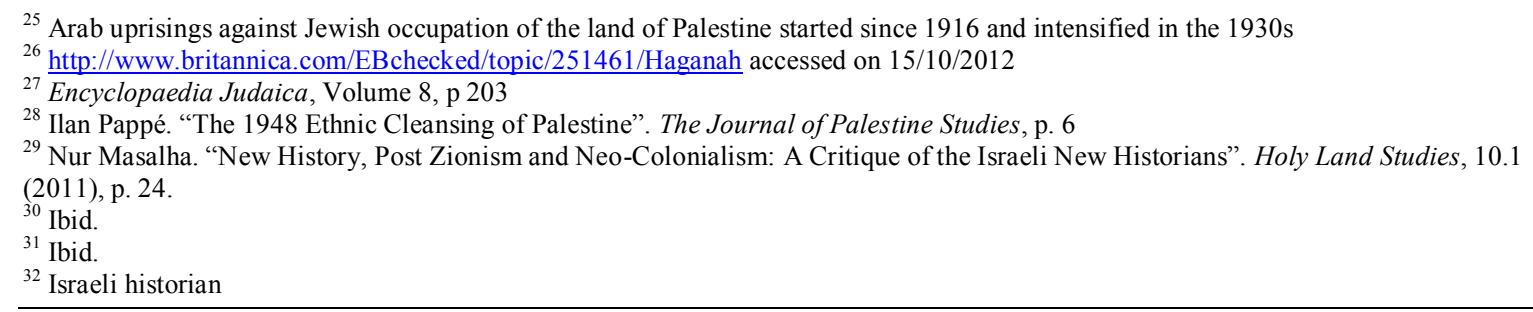


According to Nur Masalha, Shlomo Sand aspires to demonstrate that Zionist historiography hopes to reinvent the Jewish people and create a new image of the New Hebrew Man, ${ }^{33}$ which is also one of the objectives of post-Zionist historiography that intends to demonstrate that the Israeli identity is one that is self conscious and self critical. For Masalha, despite the challenging nature of the findings advanced by Benny Morris and Avi Shlaim, neither of them - or of the other Post-Zionists - managed to effectively undermine the hegemonic discourses established in official Israeli records and counter them as Ilan Pappé did. Most postZionists usually firmly believe in the "liberating" and national aspect of the Zionist movement, denying any elements that make of it a colonizer movement which in my view renders the whole Jewish metamorphosis into a muscle Jew and then into a New Hebrew Man a void and fake process that only transformed the Jewish male physiognomy but unleashed an irremediable inner need to avenge the past traumas

\section{Bibliography}

[1]. Speech of Max Nordau at the First Zionist Congress available at http://www.mideastweb.org/nordau1897.htm accessed on 15/10/2012.

[2]. Encyclopaedia Judaica, second edition, V. 03. New York: MacMillan Reference USA, 2007.

[3]. Encyclopaedia Judaica, second edition, V. 04. New York: MacMillan Reference USA, 2007.

[4]. Encyclopaedia Judaica, second edition, V. 07. New York: MacMillan Reference USA, 2007.

[5]. Encyclopaedia Judaica, second edition, V. 08. New York: MacMillan Reference USA, 2007.

[6]. Encyclopaedia Judaica, second edition, V. 09. New York: MacMillan Reference USA, 2007.

[7]. Hoedl, Klaus. "Physical Characteristics of the Jews". Journal of Jewish Studies at the CEU (1999-2001). Available at http://web.ceu.hu/jewishstudies/pdf/01 hoedl.pdf accessed on 08/10/2012.

[8]. Masalha, Nur. "New History, Post Zionism and Neo-Colonialism: A Critique of the Israeli New Historians". Holy Land Studies. Edinburgh: Edinburgh UP, 2011.

[9]. Mendes-Flohr, Paul and Jehuda Reinharz (eds). The Jew in the Modern World: A Documentary History, 2nd edition. New York, 1995.

[10]. Nwagbara, Uzoechi. "Arresting Historical Violence: Revolutionary Aesthetics and Alex La Guma's Fiction." The Journal of Pan African Studies, Vol. 4, N³ (2011).

[11]. Pappé, Ilan. "The 1948 Ethnic Cleansing of Palestine”. Journal of Palestine Studies, V. 36, N¹. California: University of California Press, 2006

[12]. Presner, Samuel Todd. Muscular Judaism: The Jewish body and the politics of regeneration. Routeledge: New York, 2007.

[13]. Riess, Steven A. "Anti-Semitism and Sport in Central Europe and the United States 1870-1932." Jews in the Gym, Judaism, Sports, and Athletics. (ed) Leonard J. Greenspoon. Creighton: Purdue UP, 2012.

[14]. Sand, Shlomo. The Invention of the Jewish People. Verso: London, 2009.

[15]. Thornhill, Randy. "Darwinian Aesthetics Informs Traditional Aesthetics.” Evolutionary Aesthetics. (eds) E. Voland; K. Grammer: 2003. Article available at http://www.kevinmacdonald.net/thornhill-aesthetics.pdf accessed on 08/10/2012.

[16]. Vertinsky, Patricia. “Anti-Semitism, Physical Culture and the Jews' Foot." Cambridge: Cambridge UP, 1999.

\footnotetext{
${ }^{33}$ Nur Masalha. "New History, Post Zionism and Neo-Colonialism: A Critique of the Israeli New Historians". Holy Land Studies, 10.1
} (2011), p. 24 